\title{
Leaching of heavy metals from steelmaking slags*
}

\author{
J. F. P. Gomes**, **** and C. G. Pinto**
}

Summary

\begin{abstract}
Leaching tests with EAF and Ladle slags were performed, using a flow through test and the standard batch test DIN 38414-S4. The previous method was used to simulate the leaching behaviour of steel slags under landfill. The chemical analysis of the leachates during this period shows, in general, for both types of slag, an increase of heavy metal releases with ageing. Standard test method DIN 38414-S4 was used to evaluate leachability of heavy metals by water in unprocessed slags. After more than one year of trials, slag samples submitted to these trials presented very low total leaching levels. The most extracted elements are calcium and magnesium. Nevertheless, in flow-through test, calcium and magnesium leached from solid slags are below $0.5 \%$ and all other metals below $0.1 \%$. Leachates obtained with DIN 38414-S4 present, as expected, higher leaching values; however, these are inferior to 5 $\%(\mathrm{Ca})$ and $1 \%$ (other elements).
\end{abstract}

Steelmaking slags. Leaching tests. Environmental impact.

\section{Lixiviación de metales pesados a partir de escorias de acero}

Resumen

Palabras clave

\begin{abstract}
Este articulo contiene los resultados obtenidos en ensayos de lixiviación de escorias de acero (horno electrico y cuchara) ejecutados siguiendo la metodologia de flujo dinámico así como el ensayo normalizado DIN 38414-S4. El primer ensayo intenta simular el comportamiento de lixiviación de las escorias en vertedero. Para las escorias ensayadas se han complementado los ensayos con el análisis químico de los lixiviados y se ha verificado un aumento de la liberación de metales pesados. El ensayo DIN 38414-S4 se ha utilizado para evaluar la lixiviación por agua de metales pesados, en muestras de escorias originales. Despues de un año de ensayos, se han observado niveles muy bajos de lixiviación. Los elementos mas lixiviados han sido calcio y magnesio. No obstante, en los ensayos de flujo dinámico, el calcio y el magnesio lixiviados de las escorias sólidas era menor de 0,5\% y el resto de los otros metales era inferior a $0,1 \%$. Los lixiviados obtenidos con el ensayo DIN 38414-S4 presentan, como era de esperar, valores mas elevados de los lixiviados: casi, $5 \%$ para el calcio y casi, $1 \%$ para todos los demás metales.
\end{abstract}

Escorias de acero. Ensayos de lixiviación. Impacto medio ambiental.

\section{INTRODUCTION}

Slags have been long viewed as valuable by-products of steel industry. Some of the recycling alternatives used worldwide include cement incorporation, cons- truction products, road base and sub-base aggregates, as well as additives used for soil improvement ${ }^{[1]}$. The application of these recycling techniques is now a reality for several decades.

In Europe, the most popular applications are ce-

\footnotetext{
* Trabajo recibido el día 8 de noviembre de 2005 y aceptado en su forma final el día 27 de junio de 2006

** Centro de Tecnologias Ambientais, Instituto de Soldadura e Qualidade, Tagus Park, Apartado 012- 2780-994 Oeiras, Portugal. Fax: 351.21.3850991 Email: ip241783@ip.pt.

*** Universidade Lusófona de Humanidades e Tecnologias, Av. Campo Grande, 376, 1749-024 Lisboa, Portugal.
} 
ment incorporation and production of road base and sub-base aggregates. According to EUROSLAG, the European Association of Slag Producers and Processors $^{[2]}$, these applications account for $42 \%$ (18.8 MTon) and $37 \%$ (16.7 MTon) of total produced slag for road construction and cement incorporation, respectively.

Although the application of such recycling techniques is, nowadays, a common practice, there are still significant slag quantities being dumped into landfills (7 \%, 3.4 MTon) or stockpiled for long periods at steel plants (3 \%, 1.2 MTon), in Europe.

One of the most significant environmental impacts when handling and reusing steel slags is leaching of soluble components from the slag matrix, when these materials are in direct contact with soil, exposed to rainwater or when in permanent contact with surface and sea waters ${ }^{[3]}$. Therefore, the knowledge about the chemical composition of leacheates and their behaviour is environmentally relevant. Several leaching tests were conducted in order to monitor the leachates composition throughout slags ageing process, and thus assess their compatibility with environmental regulations and their sound use in several applications. Leaching processes comprise contact between a liquid an a solid material, where the partial dissolution of certain components occur ${ }^{[4]}$. Therefore leaching tests show the possible occurrence of even complex chemical reactions, where the chemical species are mobilised by difusion and convection processes. These laboratorial tests show a possible contamination route of the environment via hidrologic resources and human beings. There are several physical, chemical and also biological factors that can influence the leaching process $^{[5]}$ :

a) physical factors: particle size, homogeneity of mineral phases ${ }^{[6]}$, the time scale of the process, the flow of leaching agent, the temperature, the porosity and permeability of the solid matrix and its geometry and also the hidrogeologic environment;

b) chemical factors: chemical equilibrium, kinetics, the $\mathrm{pH}$, the possibility of complexation of chemical species $^{[7]}$, the redox potential, as well as adsorption processes, ionic exchange and electrostatic attraction.

A system where leaching processes occur can be extremely complex ${ }^{[8]}$, as all the phenomena previously mentioned can happen simultaneously. All leaching processes comprise heterogenous reactions, which can be reversible or not, and quick or slow. The water phase reactions, such as acid-alkaline reactions and complexing reactions are usually quick (around some seconds), while adsorption processes occurring on the surface of oxides are slower (hours or days) and precipitation reactions $^{[8]}$, dissolution and redox processes involving solids are very slow (days to years).

According to the duration of the leaching tests, only some types of reactions could be observed in practice, and sometimes, certain time is needed until the equilibrium is reached. One should be aware, that due to kinetic and diffusional limitations, the chemical equilibrium cannot be reached during leaching tests. In spite of these limitations, leaching tests are, actually considered as a very important tool to assess environmental impact of solid waste ${ }^{[4]}$, as they could be used with to attain different objectives, as stated in table I ${ }^{[9]}$.

\section{EXPERIMENTAL}

\subsection{Slag composition}

Leaching tests were carried out with EAF and ladle slags from a Portuguese steel producer.

Prior to these tests, slag samples were subjected to elemental chemical analysis of the main oxides. Samples were digested with nitric acid at $65 \%$ on a

Table I. Main objectives of leaching tests

Tabla I. Objetivos de los ensayos de lixiviación

\begin{tabular}{|c|c|}
\hline Objective & Description \\
\hline Identification of leached components & Determine the components subjected to dissolution \\
\hline Classification of wastes & Compare the waste against conformity criteria \\
\hline Evaluate the modification of processes & $\begin{array}{l}\text { Determine if any introduced modification origin a waste with lower } \\
\text { leaching rates }\end{array}$ \\
\hline Compare treatment methods & $\begin{array}{l}\text { Determine if a treatment method results in a higher quantity of } \\
\text { contaminants }\end{array}$ \\
\hline Quality control of treatment methods & Verify the efficiency of a treatment method \\
\hline Project leaching treatment systems & Obtain typical leacheates in order to perform treatment trials \\
\hline Estimate released concentrations to the environment & Express leaching processes over time \\
\hline Determine modelling parameters & Quantify diffusion coefficients and kinetic parameters \\
\hline Risk assessment & Estimate potential environmental impacts if wastes are landfilled \\
\hline
\end{tabular}


LEACHING OF HEAVY METALS FROM STEELMAKING SLAGS LIXIVIACIÓN DE METALES PESADOS A PARTIR DE ESCORIAS DE ACERO

Table II. Chemical composition of slag samples submitted to leaching tests (\% wt)

Tabla II. Composición química de las muestras de escorias sometidas a ensayos de lixiviación (\% peso)

\begin{tabular}{lccccccc}
\hline Sample & FeO & $\mathbf{M n O}$ & $\mathbf{T i O}_{\mathbf{2}}$ & $\mathbf{A l}_{\mathbf{2}} \mathbf{O}_{\mathbf{3}}$ & $\mathbf{C a O}$ & $\mathbf{M g O}$ & $\mathbf{C r}_{\mathbf{2}} \mathbf{O}_{\mathbf{3}}$ \\
\hline Fresh EAF slag & $41.2 \pm 8$ & $3.9 \pm 0.4$ & $0.4 \pm 0.1$ & $5.2 \pm 0.8$ & $18.4 \pm 0.9$ & $3.9 \pm 0.4$ & $0.95 \pm 0.1$ \\
EAF slag aged 3 months & $41.4 \pm 8$ & $3.9 \pm 0.4$ & $0.4 \pm 0.1$ & $4.6 \pm 0.7$ & $18.5 \pm 0.9$ & $3.8 \pm 0.4$ & $1.13 \pm 0.1$ \\
EAF slag aged 6 months & $39.3 \pm 8$ & $3.8 \pm 0.4$ & $0.4 \pm 0.1$ & $4.8 \pm 0.7$ & $18.2 \pm 0.9$ & $3.6 \pm 0.4$ & $0.99 \pm 0.1$ \\
Fresh ladle slag & $2.0 \pm 0.4$ & $0.4 \pm 0.04$ & $0.2 \pm 0.05$ & $4.1 \pm 0.6$ & $54.1 \pm 2.7$ & $7.4 \pm 0.7$ & $0.03 \pm 0.03$ \\
Ladle slag aged 3 months & $8.5 \pm 1.5$ & $2.4 \pm 0.2$ & $0.2 \pm 0.05$ & $3.1 \pm 0.5$ & $38.2 \pm 1.9$ & $8.0 \pm 0.8$ & $0.24 \pm 0.02$ \\
Ladle slag aged 6 months & $1.3 \pm 0.3$ & $0.4 \pm 0.04$ & $0.2 \pm 0.05$ & $3.3 \pm 0.5$ & $46.0 \pm 2.3$ & $6.1 \pm 0.6$ & $0.06 \pm 0.02$
\end{tabular}

microwave oven, and then analysed, in duplicate, by ICP (inductively coupled plasma) in a sequential analyser Thermo Jarrel Ash Atomscan 16.

Slag samples were aged by natural weathering at a steel plant slag landfill, in the period of December 2002 to July 2003.

During the referred ageing period, slags were exposed to high atmospheric precipitation levels, especially in December $\left(280 \mathrm{l} / \mathrm{m}^{2}\right)$, January $\left(250 \mathrm{l} / \mathrm{m}^{2}\right)$, March $\left(110 \mathrm{l} / \mathrm{m}^{2}\right)$ and April $\left(130 \mathrm{l} / \mathrm{m}^{2}\right)$, reproducing the average precipitation conditions in Portugal for these months ${ }^{[10]}$.

\subsection{Leaching tests}

\subsubsection{Flow through tests}

This test was performed in a column lysimeter, simulating site-specific conditions, namely the landfill of a material and the natural leaching of pollutants from the solid matrix. The experimental set is shown in figure 1A for EAF slag, and figure 1B for ladle slag.

In the lysimeter, the slag sample is put in a way that does not create a preferential flow of water. The water used was slightly acidificated $(\mathrm{pH}=4)$ at a low flow rate $(0.15 \mathrm{ml} / \mathrm{min})$ in order to simulate natural precipitation conditions. Trials were conducted with EAF and ladle slag samples, from the same heat, in three different ageing levels (as shown in table II), for a period of 30 weeks. During laboratory trials, samples were watered every week with one litre of distilled water and the leachates collected after 3 days.

The leachates were analyzed in order to monitor relevant parameters such as heavy metals (Fe, Mn, Ti, $\mathrm{Al}, \mathrm{Ca}, \mathrm{Mg}, \mathrm{Cr}$ ), $\mathrm{pH}$ and electrical conductivity. The elemental analysis of leacheates, in duplicate, was made by ICP in a sequential analyser Thermo Jarrel Ash Atomscan 16, while pH was measured using a Crisom 2000 potentiometer, and conductivity was measured using a Metrohm conductivimeter.
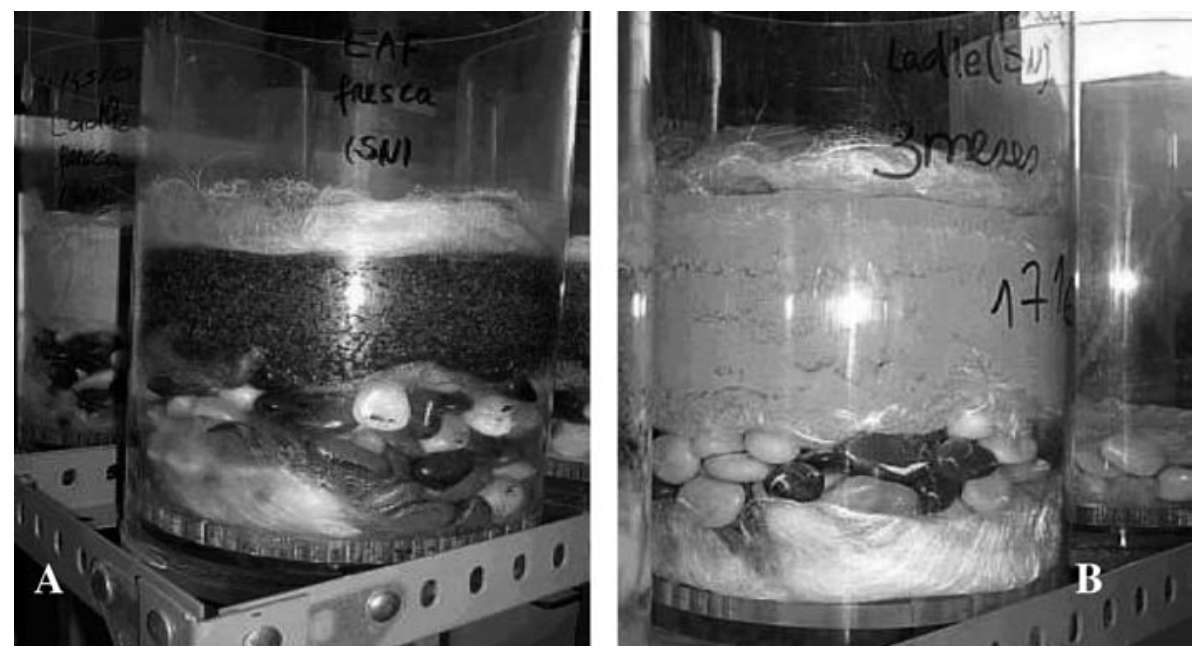

Figure 1. Experimental set-up used in flow-through test: A - EAF slag; B - Ladle slag. Layers from top to bottom: glass wool, slag sample, granite bed, perforated plate (leachate drain).

Figura 1. Equipo experimental utilizado en los ensayos de flujo dinámico: A - Escoria de horno eléctrico; B - Escoria de cuchara. Estructura del lecho: lana de vidrio, muestra de escoria, granito, placa perforada para salida de lixiviado. 

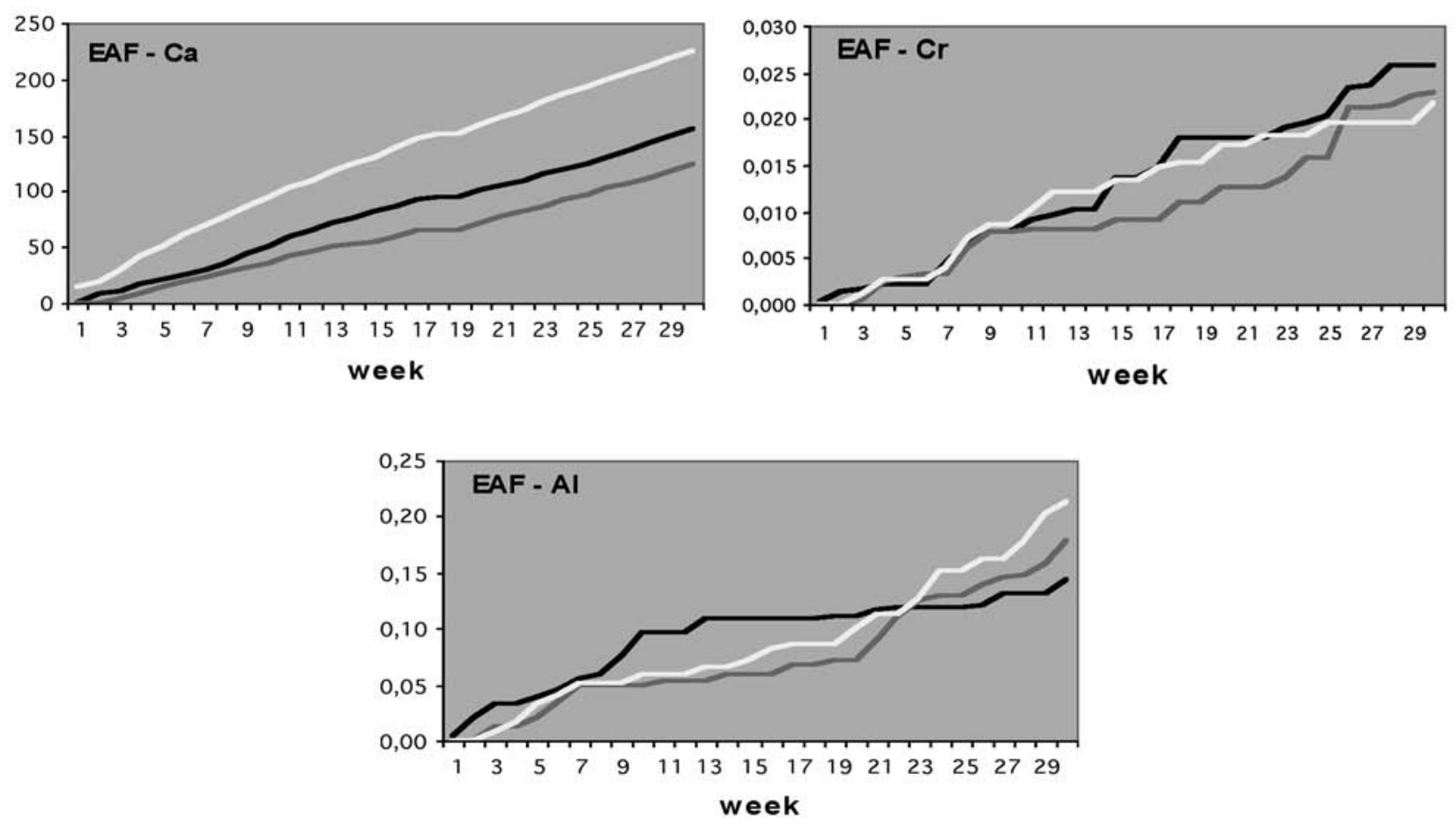

Figure 2. EAF slag leachates evolution in flow through test, for selected elements.

Figura 2. Evolución de la composición química de los lixiviados de escorias del horno en los ensayos de flujo dinámico, para elementos seleccionados.

\subsubsection{Compliance DIN 38414-S4 test}

The method DIN 38414-S4 ${ }^{[11]}$ was the regulatory test method (compliance test) used to evaluate the performance of the slags. In this test, $100 \mathrm{~g}$ of dry mass of the residue (with a particle size $<10 \mathrm{~mm}$ ) are mixed in $1000 \mathrm{ml}$ of water, and submitted to an upside down agitation, in a rotary agitator, during $24 \mathrm{~h}$ at room temperature. The solid and liquid phases are separated with a filter of $0.45 \mu \mathrm{m}$ of pore size, and the liquid phase is then analyzed. The elemental analysis of leacheates, in duplicate, was made by ICP in a sequential analyser Thermo Jarrel Ash Atomscan 16.

Trials were conducted with fresh EAF and ladle slags, as shown in Table II. The leacheates were analysed in order to monitor relevant parameters such as heavy metals (Fe, Mn, Ti, Al, Ca, Mg, Cr), pH and electrical conductivity.

\section{RESULTS AND DISCUSSION}

\subsection{Chemical composition of slags}

The chemical composition of the slags has been determined after 3 and 6 months ageing, and is presented in table II.
Despite the high precipitation levels verified, especially during the first three months of aging by weathering, the results show no significant evolution of the chemical composition. However, for ladle slag samples aged 3 months, some discrepancies in evolution could be noted, mainly when referring to $\mathrm{FeO}$, $\mathrm{MnO}, \mathrm{MgO}$ and $\mathrm{Cr}_{2} \mathrm{O}_{3}$ content. The observed concentration increase for these species is opposed to the expected reduction trend which could be attributed to lixiviation by rain water. This was found to be due to the heterogeneity of the samples, which influenced the acid digestion. However, this was not noticed for other species such as $\mathrm{TiO}_{2}$ and $\mathrm{Al}_{2} \mathrm{O}_{3}$. Nevertheless, the $\mathrm{CaO}$ content determined seem to be in accordance with the other determined species content.

\subsection{Flow through test results}

Due to the high amount of results, only some of them are presented in figure 2 for $\mathrm{Ca}, \mathrm{Cr}$, Ti and $\mathrm{Al}$. Each graphic presents the total leached quantity of an element in $\mathrm{mg} / \mathrm{kg}$ of dry sample (cumulative values) during 30 weeks of trials. Several phenomena normally occurring in these trials were observed, specifically, channelling, system clogging (in ladle samples), biological growth and oxidation of metallic iron inclusions (in EAF samples). 
Table III. Trace heavy metal concentrations $n$ fresh slags samples

Tabla III. Concentración de metales pesados en muestras de escorias originales

\begin{tabular}{|c|c|c|c|c|c|}
\hline & \multicolumn{2}{|c|}{ Trial results (mg/kg) } & \multicolumn{3}{|c|}{ Leaching Limit Values ${ }^{(2)}(\mathrm{mg} / \mathrm{kg})$} \\
\hline & $\operatorname{EAF}^{(1)}$ & Ladle $^{(1)}$ & Inert & Non hazardous & Hazardous \\
\hline total $\mathrm{Cr}$ & $0.5 \pm 0.05$ & $0.6 \pm 0.05$ & 0.5 & 10 & 70 \\
\hline As & $<0.5( \pm 0.05)$ & $<0.5( \pm 0.05)$ & 0.5 & 2 & 25 \\
\hline $\mathrm{Pb}$ & $<0.5( \pm 0.05)$ & $<0.5( \pm 0.05)$ & 0.5 & 10 & 50 \\
\hline $\mathrm{Cd}$ & $<0.04( \pm 0.004)$ & $<0.04( \pm 0.004)$ & 0.04 & 1 & 5 \\
\hline $\mathrm{Cu}$ & $0.36 \pm 0.03$ & $0.52 \pm 0.05$ & 2 & 50 & 100 \\
\hline $\mathrm{Hg}$ & $<0.01( \pm 0.001)$ & $<0.01( \pm 0.001)$ & 0.01 & 0.2 & 2 \\
\hline $\mathrm{Ni}$ & $0.18 \pm 0.02$ & $0.32 \pm 0.03$ & 0.4 & 10 & 40 \\
\hline $\mathrm{Zn}$ & $0.26 \pm 0.03$ & $0.98 \pm 0.1$ & 4 & 50 & 50 \\
\hline
\end{tabular}

(1) Average values of two samples.

(2) Leaching limit values according to Council Decision 2003/33/EC that establishes criteria and procedures for the acceptance of waste at landfills (L/S = 10 l/kg; leachates extracted according to DIN 38414 S4).

EAF leachates presented a variation of $\mathrm{pH}$ ranging from 7.5 to 10.5 and conductivity, very steady along the ageing period, with values around $20 \mathrm{mS} / \mathrm{m}$. Regarding heavy metals, the leaching of $\mathrm{Ti}$, $\mathrm{Cr}$ and $\mathrm{Al}$ doesn't seem to be affected by the ageing process, while the release of the other monitored elements increased in older samples.

Ladle leachates presented less stable values of $\mathrm{pH}$ (7.5 to 12) and conductivity, which decreases from $360 \mathrm{mS} / \mathrm{m}$ to $30 \mathrm{mS} / \mathrm{m}$. Heavy metal release increases with ageing, although the rate of leaching decreases over time.

Over the entire duration of the trials, the individual concentrations in $\mathrm{mg} / \mathrm{l}$ appeared to be independent of time for the majority of the chemical species, i.e. there is no specific tendency but an oscillating behaviour. This fact was also verified in previous similar tests reported in literature ${ }^{[1]}$.

Despite the general increasing trend of heavy metals release with ageing, after more than one year of trials, these slag samples present very low leaching levels. Calcium and magnesium leached from solid slags are below $0.5 \%$ and all other metals below $0.05 \%$.

\subsection{DIN 38414-S4 - Determination of leachability by water}

Due to the considerable high number of results, only some of them are presented in figure 3. Each graphic presents the total leached quantity of an element in $\mathrm{mg} / \mathrm{kg}$ of dry sample (cumulative values) during eight extraction cycles.

Solubility behaved very unstably in the first extraction cycles and consequently the trials were repeated eight times but no sample stabilization occurred.
In EAF samples, $\mathrm{pH}$ and conductivity values are very similar to those obtained with flow thought test, although the methods cannot be compared. Conductivity ranges from 15 to $9 \mathrm{mS} / \mathrm{m}$ in a decreasing trend line and $\mathrm{pH}$ ranges from 8 to 10 . Ladle samples present higher and more stable $\mathrm{pH}$ values along several cycles (between 11.5 and 12.5) and conductivities range between $130 \mathrm{mS} / \mathrm{m}$ and $450 \mathrm{mS} / \mathrm{m}$.

Extraction levels are, as expected, higher than in the flow-through test, since DIN 38414-S4 is a forced extraction method. Nevertheless, in what concerns leachability by water, these slag samples present very low levels, ranging from $0.003 \%(\mathrm{Fe})$ to $1.1 \%(\mathrm{Ca})$ in $\mathrm{EAF}$ and $0.009 \%(\mathrm{Mn})$ to $4.7 \%(\mathrm{Ca})$ in ladle.

The presence of other heavy metals such as arsenic, lead, cadmium, copper, mercury, nickel and zinc, usually present in residual quantities, was also investigated in fresh samples. The concentrations obtained are presented in table III.

The results presented in table III were compared with the limit values defined by Council Decision 2003/33/EC, that establishes criteria and procedures for the acceptance of waste at landfills, defining leaching limit values (LLV) for several heavy metals in wastes. As observed, all values were found to be below the LLV for inert wastes, except for chromium in the ladle. It must be refered, however, that these results refer to fresh samples that have not been submitted to subsequent stabilization, i.e., unprocessed (fresh) slag.

The low solubility observed in these trials is probably related to mineral components bounded within stable crystalline phases and also the leaching conditions, namely the basic $\mathrm{pH}$. In fact, the $\mathrm{pH}$ of a solution greatly affects the solubility of most minerals like 

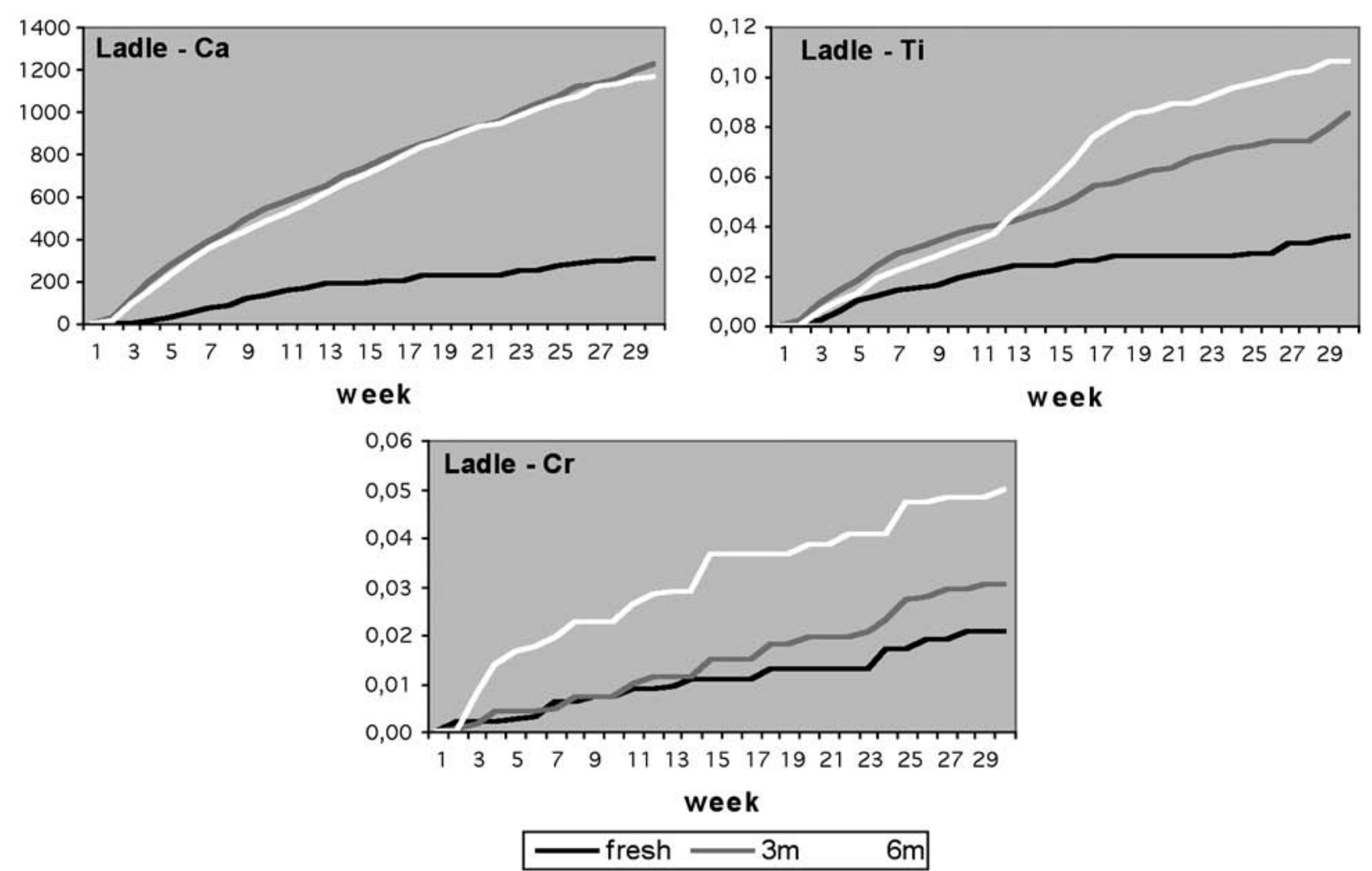

Figure 3. Ladle slag leachates evolution in flow through test, for selected elements.

Figura 3. Evolución de la composición química de los lixiviados de escorias de cuchara en los ensayos de flujo dinámico, para elementos seleccionados.

iron, zinc, copper, manganese and cadmium, which decrease for higher $\mathrm{pH}$ values.

Normally, chromium concentrations in the leachates tend to be low because ions are bound within stable crystalline phases. However, there are certain types of soil (for instance, soils with high content of oxidized manganese or other species that act as electron receptors) that promote oxidation of $\mathrm{Cr}^{3+}$ to $\mathrm{CrO}_{4}^{2-}$. On the other hand, if leachates are put in presence of oxygenated waters (with $\mathrm{pH}$ levels above 5), $\mathrm{CrO}_{4}{ }^{2-}$ is bound to occur, as this species is stable under these conditions.

The trials carried out confirmed the information consulted in several references ${ }^{[1 \text { and } 2]}{ }^{2}$, referring that, except for chromium (particularly in the hexavalent form), the leaching of other elements is not relevant in terms of environmental impact.

The reuse of steel slags is highly recommended not only to increase the added value of this steel industry by-product but also to save natural resources and, in some applications, to achieve energy savings, like the cement industry. Low value applications, such as dumping, stockpiling or land filling must be replaced by other valuable alternatives, which imply slag treatment and processing before its reuse. Nowadays, the pre-treatment of slag or its stabilization before reuse is, in fact, a common practice, due to the growing demand of slags for high quality applications ${ }^{[1]}$.

\section{CONCLUSIONS}

The leaching of heavy metals from slags along the ageing period of these materials was investigated. The cumulative leaching values obtained after more than one year of trials, are very low, which is quite positive in terms of the environmental compatibility of these materials. The trials performed with DIN batch test are particularly optimistic since this is a "worst case scenario" method, i.e. it can exaggerate the leaching potential.

The obtained results also confirm that the natural leaching of soluble components from slags is not a continuous process but an intermittent one. Leaching increased along the slag ageing period and, generally, no stabilization occurred after 30 weeks, meaning that it is, in fact, a slow process that can take months, or even years to be completed. 

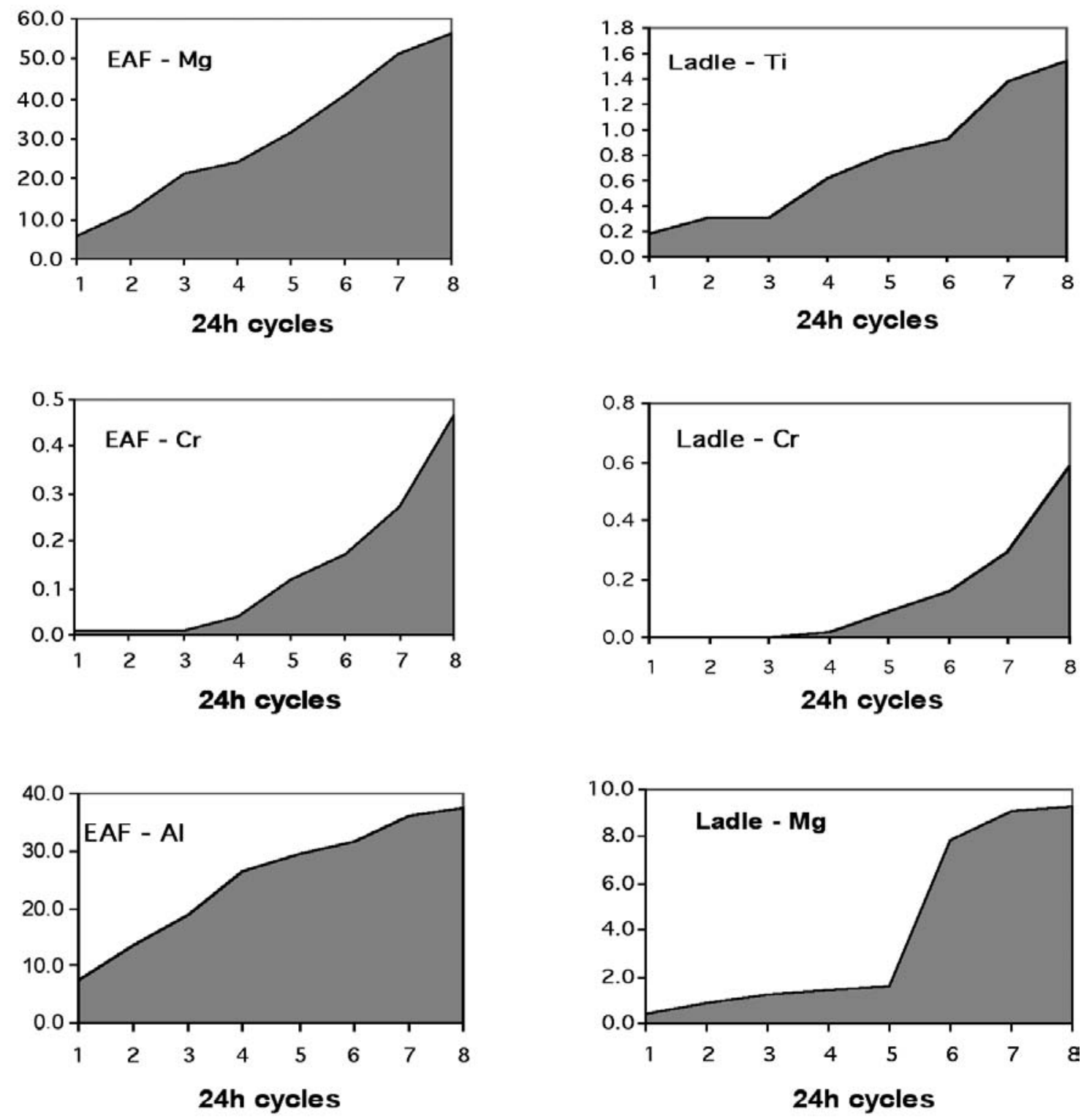

Figure 4. Cumulative slag leachates evolution in DIN 38414-S4 test, for selected. elements.

Figura 4. Evolución acumulada de la composición química de los lixiviados de escorias segun DIN 38414-S4, para elementos seleccionados.

Other factors rather than metal concentrations have to be considered when accessing the environmental impact of slags, such as accumulation effects resulting from long exposing periods, the solubility and mobility of chemical species, their biological availability and the properties of solid matrix (porosity, permeability $)^{[12)}$.

Therefore, the reuse of slags without a proper previous treatment or the uncontrolled dumping can have negative effects on the environment in the long term. Thus, the pre-treatment of slag or its stabilization before reuse is recommended, even for low value applications.

\section{Acknowledgments}

Financial support by the European Commission, Programme ECSC, through Contract No $7210-\mathrm{PR}-302$ is gratefully acknowledged.

\section{REFERENCES}

[1] R. ANIGSTEIN, Potential Recycling of Scrap Metal from Nuclear Facilities, Vol.1, Part I, United States Environmental Protection Agency, Raleigh, USA, 2001, pp. 4-1/4-30.

[2] H. MOTZ, Proc. $3^{\text {rd }}$ European Slag Conference, 
EUROSLAG Ed., Brussels, Belgium, 2003, pp. 120-123.

[3] R. MILLER AND R. DONAHUE, Soils in Our Environment, $7^{\text {th }}$ Edition, Prentice Hall, London, United Kingdom, 1995, pp. 230-235.

[4] M. MARTiN, F. LÓPEZ, A. LÓPEZ-DELGADO, C. PÉREZ AND F. ALGUACIL, Rev. Metal Madrid 41 (2005) 324-328.

[5] M. MARTIN, F. LÓPEZ AND F. ALGUACIL, Rev. Metal. Madrid 41 (2005) 292-297.

[6] P. NAVARRO, C. VARGAS AND F. ALGUACIL, Rev. Metal. Madrid 41 (2005) 107-110.

[7] P. NAVARRO, C. VARGAS, R. ALVAREZ AND F. ALGUACIL, Rev. Metal. Madrid 41 (2005) 12-20.
[8] P. NAVARRO, C. VARGAS, E. ARAYA, I. MARTIN AND F. ALGUACIL, Rev. Metal. Madrid 41 (2005) 409-412.

[9] Compendium of Waste Leaching Tests, Report EPS 3/HA/7, Environment Canada, Ottawa, Canada, 1990, pp. 30-40.

[10] Climatologia-Portugal, Instituto de Meteorologia, www.meteo.pt, pp.1.

[11] DIN 38414-S4, Deutsche Norm, Teil 4 Okt, 1984, pp. 464-475,

[12] Summary report on RTD on iron and steel slag: Development and perspectives, European Commission, Brussels, Belgium, 1999, pp. 10-20. 